\title{
LATERAL BRANCH INDUCTION AT NURSERY WITH GROWTH REGULATORS IN 'MAXI GALA' APPLE TREES GRAFTED ON FOUR ROOTSTOCKS
}

\author{
Leo Rufato ${ }^{a}$, Lucas De Ross Marchioretto ${ }^{a}$,*, Júlio César Orlandi ${ }^{a}$, Micheli Fochesato Michelon ${ }^{a}$, \\ Andrea De Rossi ${ }^{\mathrm{b}}$, Guilherme Fontanella Sander ${ }^{\mathrm{a}}$, Tiago Afonso de Macedo ${ }^{\mathrm{a}}$ \\ ${ }^{a}$ Department of Vegetal Production, State University of Santa Catarina (UDESC), Centre of Agroveterinary Sciences. Avenida Luis de Camões, 2090, Lages/SC, 88520- \\ OOO, Brazil \\ ${ }^{\mathrm{b}}$ EMBRAPA Grape and Wine, Research Station of Temperate Climate Fruticulture (EFTC). Br. 116, s/n, Vacaria/RS, 95200-000, Brazil
}

A R T I C L E I N F O

\section{Keywords:}

lateral branching

exogenous hormones

Malus domestica Borkh.

uniformity

\begin{abstract}
A B S T R A C T
Apple production in Southern Brazil has been increasing along the past decade, and part of this was due to the introduction of more adapted dwarfing rootstocks and consequently increased tree density in the orchards. Looking for obtaining early beariness, the use of branched nursery trees is one of the most important steps. The objective of this experiment was to determine the effects of plant the growth regulators Benzyladenine (BA),

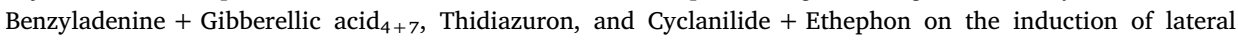
branches of 'Maxi Gala' apple trees at nursery, grafted on the rootstocks G.202, G.213, M.9, and Marubakaido with M.9 interstem. The growth regulators Benzyladenine (BA), and Benzyladenine + Gibberellic acid $4+7 \operatorname{are}$ the most effective on improving tree's architecture and on increasing the number of spurs, for all scion-rootstock combinations tested. Plant growth regulators at elevated doses strongly interrupt apical dominance and stimulate an elevated number of lateral branches with narrower crotch angles.
\end{abstract}

\section{INTRODUCTION}

Apple production in Southern Brazil have been increasing linearly along the past decades (Anuário Brasileiro da Maçã, 2017), as new technologies are implemented in the orchards. Recently, the introduction of the Geneva rootstocks in commercial apple orchards allowed reduced plant spacing and elevated densities. However, the increased number of plants increases substantially the implementation costs, making it necessary the orchard to be precocious targeting for quicker revenues.

With the introduction of the European Apple Canker (Nectria galligena) in Brazil, in the year of 2013 the Brazilian Ministery of Agriculture, through the normative instruction $n^{\circ} 20 / 2013$, determined that apple nurseries should be located at least 10 kilometers away from orchards with incidence of the disease (MAPA, 2013). Although, the nursery areas that fit this requirement are located in warm regions, which make the apple trees to grow vigorously the main stem and release very few or no lateral branches. In the Southern Brazilian conditions, nursery companies usually adopt protocols imported from traditional regions of apple production around the globe to use in local conditions with variable and eventually inconsistent results. Furthermore, little is known about the plant's response (i.e. scion's architecture, lateral branch emissions, etc.) and the interaction of plant growth regulators with rootstocks, in such environmental conditions of warmer weather and elevated annual precipitation, which substancially increases the tree's vigor.

Rootstocks affect directly the scion's architecture, as a 'Royal Gala' scion grafted on 'Royal Gala' self-rooted stool, made the primary and secondary scion shoots to be numerous and vigorous, whereas, the same scion grafted on M.9 dwarfing rootstock had fewer lateral branches (Hooijdonk et al., 2011). The management of apple trees at nursery is basically focused on altering the dynamics of apical dominance, and so, inducing lateral bud break. It can be reached by changing the balance of endogenous auxin:cytokinin ratio to induce bud break (Bangerth et al., 2000; Sazo and Robinson, 2011).

The plant growth regulators benziladenine (BA) alone or in combination with gibberelin $\left(\mathrm{GA}_{4+7}\right)$ sprayed oftentimes are vastly reported to improve apple plant quality at nursery by increasing the number and the length of lateral branches as well as the crotch angle, especially on dwarfing rootstocks, that eventually induce few lateral

\footnotetext{
* Corresponding author.

E-mail address: lucasdeross@hotmail.com (L.D.R. Marchioretto).
} 
Table 1

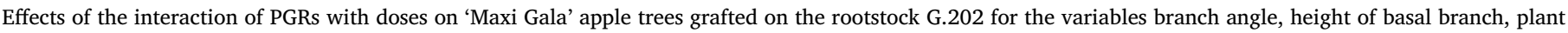
height, and spur number.

\begin{tabular}{|c|c|c|c|c|c|c|c|c|c|}
\hline \multicolumn{5}{|c|}{$2015 / 2016$} & \multicolumn{5}{|c|}{$2016 / 2017$} \\
\hline & $\begin{array}{l}\text { Branch } \\
\text { angle }\left(^{\circ}\right)\end{array}$ & $\begin{array}{c}\text { Height of } \\
\text { basal } \\
\text { branch } \\
(\mathrm{cm})\end{array}$ & $\begin{array}{l}\text { Plant } \\
\text { height } \\
(\mathrm{cm})\end{array}$ & $\begin{array}{c}\text { Spur } \\
\text { number }\end{array}$ & & $\begin{array}{l}\text { Branch } \\
\operatorname{angle}\left({ }^{\circ}\right)\end{array}$ & $\begin{array}{c}\text { Height of } \\
\text { basal } \\
\text { branch } \\
\text { (cm) }\end{array}$ & $\begin{array}{l}\text { Plant } \\
\text { height } \\
\text { (cm) }\end{array}$ & $\begin{array}{c}\text { Spur } \\
\text { number }\end{array}$ \\
\hline $\begin{array}{l}\text { Dose } \\
\left(\mathrm{ml} \cdot \mathrm{L}^{-1}\right)\end{array}$ & \multicolumn{4}{|c|}{ Benziladenine } & $\begin{array}{c}\text { Dose } \\
\left(\mathrm{ml} \cdot \mathrm{L}^{-1}\right)\end{array}$ & \multicolumn{4}{|c|}{ Benziladenine } \\
\hline 0 & 60 & 50 & 210 & 4 & 0 & 64 & 78 & 200 & 2 \\
\hline 1250 & 59 & 39 & 206 & 44 & 2000 & 57 & 63 & 201 & 9 \\
\hline 2500 & 53 & 35 & 216 & 7 & 3000 & 52 & 57 & 189 & 7 \\
\hline 3750 & 49 & 34 & 201 & 9 & 4000 & 54 & 54 & 189 & 10 \\
\hline Linear & $*$ & $* *$ & ns & $* *$ & Linear & $* *$ & $* * *$ & ns & $* * *$ \\
\hline Quadratic & ns & ns & ns & ns & Quadratic & ns & ns & ns & ns \\
\hline $\begin{array}{l}\text { Dose } \\
\left(\mathrm{ml} \cdot \mathrm{L}^{-1}\right)\end{array}$ & \multicolumn{4}{|c|}{$\mathrm{BA}+\mathrm{GA}_{4+7}$} & $\begin{array}{c}\text { Dose } \\
\left(\mathrm{ml} \cdot \mathrm{L}^{-1}\right)\end{array}$ & \multicolumn{4}{|c|}{$\mathrm{BA}+\mathrm{GA}_{4+7}$} \\
\hline 0 & 60 & 50 & 210 & 4 & 0 & 63 & 89 & 203 & 1 \\
\hline 1250 & 59 & 44 & 198 & 4 & 2500 & 57 & 62 & 205 & 5 \\
\hline 2500 & 57 & 44 & 197 & 6 & 5000 & 57 & 58 & 198 & 9 \\
\hline 3750 & 55 & 37 & 200 & 9 & 7500 & 53 & 61 & 191 & 8 \\
\hline Linear & ns & ns & ns & $*$ & Linear & $* *$ & $* * *$ & ns & $* * *$ \\
\hline Quadratic & ns & ns & ns & ns & Quadratic & ns & $* *$ & ns & $*$ \\
\hline $\begin{array}{l}\text { Dose } \\
\left(\mathrm{ml} \cdot \mathrm{L}^{-1}\right)\end{array}$ & \multicolumn{4}{|c|}{ Thidiazuron } & $\begin{array}{c}\text { Dose } \\
\left(\mathrm{ml} \cdot \mathrm{L}^{-1}\right)\end{array}$ & \multicolumn{4}{|c|}{ Cyclanilide+ethephon } \\
\hline 0 & 60 & 50 & 210 & 4 & 0 & 61 & 91 & 213 & 2 \\
\hline 125 & 53 & 47 & 210 & 10 & 25 & 59 & 45 & 177 & 6 \\
\hline 250 & 46 & 44 & 153 & 11 & 50 & 69 & 47 & 190 & 9 \\
\hline 375 & 49 & 46 & 193 & 14 & 75 & 61 & 43 & 183 & 8 \\
\hline Linear & ns & ns & ns & $* * *$ & Linear & ns & $*$ & ns & $* * *$ \\
\hline Quadratic & ns & ns & ns & ns & Quadratic & ns & ns & ns & ns \\
\hline
\end{tabular}

${ }^{\mathrm{ns}}$ Non-significant according to the polynomial orthogonal contrasts. $*$, $* *$, and $* * *$ Significant for $5 \%, 1 \%$ and $0.1 \%$, respectively.

branches on the scion (Volz et al., 1994). Cyclanilide is a chemical used to reduce shoot growth, and in diminishing apical dominance by stimulating lateral branch emissions on apple trees (Eflving and Visser, 2005). Cyclanilide induces the formation of lateral branches, but at elevated rates it may reduce the apple plant's height and shoot growth, while $\mathrm{BA}$ or $\mathrm{BA}+\mathrm{GA}_{4+7}$ induce lateral branches without affecting the growth rate (Robinson and Sazo, 2014).

Thidiazuron (TDZ) is a very powerful source of cytokinin that can not be conjugated by the plant, and so it has been reported to be effective in inducing bud break even in more than seven-year dormant buds (De Martin et al., 2017), and, in peach trees grown in warm climate, it was the most efective agent to induce bud break, especially when combined with mineral oil (Erez et al., 2008).

It is still unknown the effects of plant growth regulators on the induction of lateral branches at Southern Brazilian conditions. Thus, the objective of this experiment was to determine the response of 'Maxi Gala' apple trees grafted on the rootstocks G.202, G.213, M.9 and Marubakaido with M.9 interstem treated with different doses of the plant growth regulators benzyladenine, benzyladenine + gibberellic $\operatorname{acid}_{4+7}$, thidiazuron, and cyclanilide + ethephon.

\section{MATERIAL AND METHODS}

\subsection{Experimental site description}

The experiment was carried out in the years of 2015/16 and 2016/ 17 in a commercial nursery belonging to Randon Agrosilvopastoril Ltda. (RASIP), located at the municipality of Esmeralda-RS with geographical coordinates of $27^{\circ} 57^{\prime} 46^{\prime \prime} \mathrm{S} 51^{\circ} 06^{\prime} 14^{\prime \prime} \mathrm{W}$ and and mean elevation of $910 \mathrm{~m}$ above sea level.

According to the Köeppen climate classification, the climate of the region is classified as $\mathrm{Cfb}$ : humid subtropical with mild summer. The mean annual temperature is $16.1{ }^{\circ} \mathrm{C}$, and the mean annual precipitation is $1806 \mathrm{~mm}$ (Instituto de Pesquisas Agronômicas, 1989).

The predominant soil in the region is a deep oxisol, well drained, with heavy clay, highly acid, with high organic matter and exchangeable aluminum (Streck et al., 2008).

\subsection{Subject of study}

At the nursery, it was selected uniform apple tree plants grafted on four rootstocks: G.202, G.213, M.9 and Marubakaido with a $25 \mathrm{~cm} \mathrm{M.9}$ interstem. The latter rootstock combination (Marubakaido/M.9 
Table 2

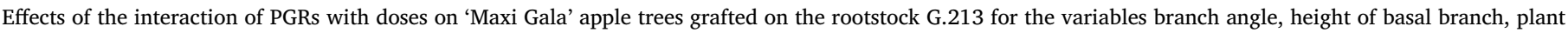
height, and spur number.

\begin{tabular}{|c|c|c|c|c|c|c|c|c|c|}
\hline \multicolumn{5}{|c|}{$2015 / 2016$} & \multicolumn{5}{|c|}{$2016 / 2017$} \\
\hline & $\begin{array}{l}\text { Branch } \\
\text { angle }\left(^{\circ}\right)\end{array}$ & $\begin{array}{c}\text { Height of } \\
\text { basal } \\
\text { branch } \\
(\mathrm{cm})\end{array}$ & $\begin{array}{l}\text { Plant } \\
\text { height } \\
(\mathrm{cm})\end{array}$ & $\begin{array}{c}\text { Spur } \\
\text { number }\end{array}$ & & $\begin{array}{l}\text { Branch } \\
\operatorname{angle}\left(^{\circ}\right)\end{array}$ & $\begin{array}{c}\text { Height of } \\
\text { basal } \\
\text { branch } \\
\text { (cm) }\end{array}$ & $\begin{array}{l}\text { Plant } \\
\text { height } \\
\text { (cm) }\end{array}$ & $\begin{array}{c}\text { Spur } \\
\text { number }\end{array}$ \\
\hline $\begin{array}{l}\text { Dose } \\
\left(\mathrm{ml} \cdot \mathrm{L}^{-1}\right)\end{array}$ & \multicolumn{4}{|c|}{ Benziladenine } & $\begin{array}{c}\text { Dose } \\
\left(\mathrm{ml} \cdot \mathrm{L}^{-1}\right)\end{array}$ & \multicolumn{4}{|c|}{ Benziladenine } \\
\hline 0 & 69 & 36 & 226 & 4 & 0 & 61 & 55 & 193 & 3 \\
\hline 1250 & 56 & 32 & 225 & 4 & 2000 & 62 & 38 & 187 & 8 \\
\hline 2500 & 55 & 32 & 208 & 4 & 3000 & 63 & 42 & 187 & 8 \\
\hline 3750 & 55 & 27 & 207 & 7 & 4000 & 59 & 36 & 187 & 10 \\
\hline Linear & $* *$ & $*$ & $* *$ & ns & Linear & ns & $*$ & ns & $* *$ \\
\hline Quadratic & ns & ns & ns & ns & Quadratic & ns & $\mathrm{ns}$ & ns & ns \\
\hline $\begin{array}{l}\text { Dose } \\
\left(\mathrm{ml} \cdot \mathrm{L}^{-1}\right)\end{array}$ & \multicolumn{4}{|c|}{$\mathrm{BA}+\mathrm{GA}_{4+7}$} & $\begin{array}{c}\text { Dose } \\
\left(\mathrm{ml} \cdot \mathrm{L}^{-1}\right)\end{array}$ & \multicolumn{4}{|c|}{$\mathrm{BA}+\mathrm{GA}_{4+7}$} \\
\hline 0 & 69 & 36 & 226 & 4 & 0 & 62 & 56 & 194 & 2 \\
\hline 1250 & 59 & 36 & 227 & 2 & 2500 & 58 & 46 & 194 & 6 \\
\hline 2500 & 58 & 30 & 216 & 5 & 5000 & 54 & 49 & 197 & 9 \\
\hline 3750 & 54 & 28 & 211 & 5 & 7500 & 56 & 48 & 184 & 11 \\
\hline Linear & $* * *$ & ns & ns & ns & Linear & $*$ & ns & ns & $* * *$ \\
\hline Quadratic & ns & ns & ns & ns & Quadratic & ns & ns & ns & ns \\
\hline $\begin{array}{l}\text { Dose } \\
\left(\mathrm{ml} \cdot \mathrm{L}^{-1}\right)\end{array}$ & \multicolumn{4}{|c|}{ Thidiazuron } & $\begin{array}{c}\text { Dose } \\
\left(\mathrm{ml} \cdot \mathrm{L}^{-1}\right)\end{array}$ & \multicolumn{4}{|c|}{ Cyclanilide+ethephon } \\
\hline 0 & 69 & 36 & 226 & 4 & 0 & 64 & 64 & 194 & 4 \\
\hline 125 & 47 & 38 & 206 & 8 & 25 & 62 & 36 & 193 & 5 \\
\hline 250 & 49 & 43 & 207 & 10 & 50 & 67 & 37 & 192 & 11 \\
\hline 375 & 46 & 42 & 201 & 11 & 75 & 70 & 34 & 187 & 9 \\
\hline Linear & $* *$ & ns & ns & $* * *$ & Linear & ns & $*$ & ns & $*$ \\
\hline Quadratic & $* * *$ & ns & ns & ns & Quadratic & ns & ns & ns & ns \\
\hline
\end{tabular}

${ }^{\mathrm{ns}}$ Non-significant according to the polynomial orthogonal contrasts. $*$, $* *$, and $* * *$ Significant for $5 \%, 1 \%$ and $0.1 \%$, respectively.

interstem) is widely adopted in the apple croping systems in Brazil, as an anternative to the rootstock M.7, used in the first orchards, back in the 80 's, as it was highly susceptible to wooly apple aphids; then, a feasible alternative was the use of Marubakaido rootstocks, which are imune to wooly aphids, and Fusarium sp. root rot, but it is highly vigorous; Although, to overcome this, it was adopted the use of interstem of $25 \mathrm{~cm}$ of M.9, to control scion vigor, and it is the most used rootstock combination in the Brazilian apple orchards, even in replant areas, as Marubakaido is tolerant to replant desease (Denardi, 2002). Prior to planting, all the plant material remained thoughtout a period of 30 days at 2 to $3{ }^{\circ} \mathrm{C}$ in a moisturized refrigetation chamber to heal the graft union, and to the material to reach enough chill hours for getting a perfect bud break, as 'Gala' apples require 600 chill hours below $7.2^{\circ} \mathrm{C}$ (Petry et al., 2006).

In the first year, the planting occurred on September $2^{\text {nd }}, 2015$ at the nursery field and was harvested in June $28^{\text {th }}, 2016$ in a total of 332 days of development. On the second year the planting occurred in August $29^{\text {th }}, 2016$ and was harvest in July $17^{\text {th }}, 2017$ in a total of 325 days of development in the field. On both seasons the spacing among plants was $30 \mathrm{~cm}$ between trees and $80 \mathrm{~cm}$ between rows.

\subsection{Treatments}

In the first year the treatments consisted of Benziladenine (BA) and Benziladenine plus Giberellic acid (BA $+\mathrm{GA}_{4+7}$ ) both at the doses of 0 , 250, 500 and $750 \mathrm{ml} . \mathrm{L}^{-1}$, of the commercial product Maxcel ${ }^{\circ}$, and Promalin", respectively, and Thidiazuron (TDZ) at the doses of 0, 25, 50 and $75 \mathrm{ml} . \mathrm{L}^{-1}$, of the commercial product Dropp ${ }^{\oplus}$.

In the second year the treatments consisted of Benziladenine and Benziladenine plus Giberellic acid (BA $\left.+\mathrm{GA}_{4+7}\right)$ at the doses of 0,500 , 1000 and $1500 \mathrm{ml}^{-1} \mathrm{~L}^{-1}$, of the commercial product Maxcel ${ }^{\circ}$, and Promalin , respectively, and cyclanilide plus ethephon at the doses of 0 , 12.5, 25 and $37.5 \mathrm{ml}^{-\mathrm{L}^{-1}}$ of the commercial product Finish ${ }^{\circ}$.

\subsection{Proceedings}

In the first season $(2015 / 2016)$ the sprays begun when the plants reached a mean height of $50 \mathrm{~cm}$ above the graft union, on Nov. $06^{\text {th }}$, 2015. All treatments were sprayed every 14 days, and the PGRs were applied five times on the trees throughout the season. The total amount of Benziladenine, and $\mathrm{BA}+\mathrm{GA}_{4+7}$ sprayed throughout the season was $0,1250,2500$ and $3750 \mathrm{ml} / \mathrm{L}^{-1}$, and thidiazuron was $0,125,250$ and $375 \mathrm{ml} . \mathrm{L}^{-1}$. 
Table 3

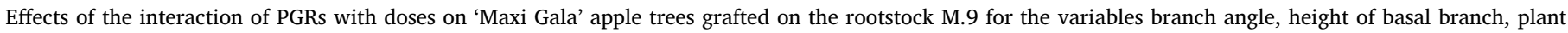
height, and spur number.

\begin{tabular}{|c|c|c|c|c|c|c|c|c|c|}
\hline \multicolumn{5}{|c|}{$2015 / 2016$} & \multicolumn{5}{|c|}{$2016 / 2017$} \\
\hline & $\begin{array}{l}\text { Branch } \\
\text { angle }\left(^{\circ}\right)\end{array}$ & $\begin{array}{c}\text { Height of } \\
\text { basal } \\
\text { branch } \\
\text { (cm) }\end{array}$ & $\begin{array}{l}\text { Plant } \\
\text { height } \\
(\mathrm{cm})\end{array}$ & $\begin{array}{c}\text { Spur } \\
\text { number }\end{array}$ & & $\begin{array}{l}\text { Branch } \\
\text { angle }\left(^{\circ}\right)\end{array}$ & $\begin{array}{c}\text { Height of } \\
\text { basal } \\
\text { branch } \\
\text { (cm) }\end{array}$ & $\begin{array}{l}\text { Plant } \\
\text { height } \\
\text { (cm) }\end{array}$ & $\begin{array}{c}\text { Spur } \\
\text { number }\end{array}$ \\
\hline $\begin{array}{l}\text { Dose } \\
\left(\mathrm{ml} . \mathrm{L}^{-1}\right)\end{array}$ & \multicolumn{4}{|c|}{ Benziladenine } & $\begin{array}{c}\text { Dose } \\
\left(\mathrm{ml} . \mathrm{L}^{-1}\right)\end{array}$ & \multicolumn{4}{|c|}{ Benziladenine } \\
\hline 0 & 0 & 58 & 158 & 1 & 0 & 62 & 43 & 158 & 4 \\
\hline 1250 & 33 & 45 & 145 & 1 & 2000 & 65 & 45 & 151 & 6 \\
\hline 2500 & 49 & 42 & 141 & 7 & 3000 & 62 & 45 & 148 & 5 \\
\hline 3750 & 44 & 30 & 134 & 7 & 4000 & 62 & 43 & 154 & 9 \\
\hline Linear & $* *$ & $*$ & $* *$ & $* * *$ & Linear & ns & ns & ns & $*$ \\
\hline Quadratic & $* * *$ & ns & ns & ns & Quadratic & ns & ns & ns & ns \\
\hline $\begin{array}{l}\text { Dose } \\
\left(\mathrm{ml} \cdot \mathrm{L}^{-1}\right)\end{array}$ & \multicolumn{4}{|c|}{$\mathrm{BA}+\mathrm{GA}_{4+7}$} & $\begin{array}{c}\text { Dose } \\
\left(\mathrm{ml} \cdot \mathrm{L}^{-1}\right)\end{array}$ & \multicolumn{4}{|c|}{$\mathrm{BA}+\mathrm{GA}_{4+7}$} \\
\hline 0 & 0 & 58 & 158 & 1 & 0 & 63 & 62 & 167 & 4 \\
\hline 1250 & 51 & 46 & 164 & 4 & 2500 & 58 & 53 & 161 & 5 \\
\hline 2500 & 46 & 38 & 155 & 4 & 5000 & 56 & 49 & 162 & 6 \\
\hline 3750 & 50 & 30 & 157 & 5 & 7500 & 53 & 45 & 153 & 8 \\
\hline Linear & $* *$ & $*$ & ns & $*$ & Linear & $* *$ & $*$ & ns & $* * *$ \\
\hline Quadratic & $* * *$ & ns & ns & ns & Quadratic & ns & ns & ns & ns \\
\hline $\begin{array}{l}\text { Dose } \\
\left(\mathrm{ml} \cdot \mathrm{L}^{-1}\right)\end{array}$ & \multicolumn{4}{|c|}{ Thidiazuron } & $\begin{array}{c}\text { Dose } \\
\left(\mathrm{ml} \cdot \mathrm{L}^{-1}\right)\end{array}$ & \multicolumn{4}{|c|}{ Cyclanilide+ethephon } \\
\hline 0 & 0 & 58 & 158 & 1 & 0 & 60 & 80 & 159 & 3 \\
\hline 125 & 18 & 68 & 164 & 5 & 25 & 77 & 38 & 151 & 7 \\
\hline 250 & 20 & 48 & 140 & 8 & 50 & 69 & 42 & 151 & 9 \\
\hline 375 & 32 & 49 & 149 & 12 & 75 & 63 & 35 & 147 & 8 \\
\hline Linear & $* * *$ & ns & ns & $* * *$ & Linear & ns & $* *$ & ns & $*$ \\
\hline Quadratic & ns & ns & ns & ns & Quadratic & $*$ & $* *$ & ns & $* *$ \\
\hline
\end{tabular}

${ }^{n s}$ Non-significant according to the polynomial orthogonal contrasts. $*$, $* *$, and $* * *$ Significant for $5 \%, 1 \%$ and $0.1 \%$, respectively.

In the second season $(2016 / 2017)$ the sprays begun when the plants reached a mean height of $60 \mathrm{~cm}$ above the graft union, on Nov. $25^{\text {th }}$, 2016. All treatments were sprayed every 14 days, but at different times. Benziladenine at the doses of 500 and $1000 \mathrm{ml} . \mathrm{L}^{-1}$ were sprayed four times in a total of 2000 and $4000 \mathrm{ml}^{-\mathrm{L}^{-1}}$, respectively, and the dose of $1500 \mathrm{ml} . \mathrm{L}^{-1}$ was sprayed two times in a total of $3000 \mathrm{ml} . \mathrm{L}^{-1}$ throughout the season. All doses of $\mathrm{BA}+\mathrm{GA}_{4+7}$ were sprayed five times in a total of $0,2500,5000$ and $7500 \mathrm{ml} . \mathrm{L}^{-1}$ throughout the season. All doses of cyclanilide plus ethephon were sprayed two times in a total of $0,25,50$, and $75 \mathrm{ml} . \mathrm{L}^{-1}$ throughout the season.

In both years the sprays were done with a backpack $\mathrm{CO}_{2}$ pressurized sprayer equipped with a full cone tip nozzle. During the application, it was delivered a single spray directed to the apical meristem/leaves of all treated plants.

\subsection{Variables of the study}

When the leaves abscised in both years, it was obtained tree height by measureing the tree from the graft union to the apical meristem with a retractable colunm ruler. For the number and length of lateral branches, it was only considered the ones with length above $10 \mathrm{~cm}$, and the emissions up to $10 \mathrm{~cm}$ were classified as spurs. Branch angle was measured by placing a $180^{\circ}$ degree protractor at the union of the branck with the trunk. The height of the first basal branch was considered as the distance from the graft union until the first emission above it. Root volume was determined only in $2015 / 2016$, and it was obtained when the nursery begun to harvest the plants. The root system of the plants were immersed in a graduated bucket to determine the water displacement and the volume of the root system.

\subsection{Experimental design}

The experimental design adopted was a split-split plot randomized complete block with three replications of five plants per replicate. Each year of the experiment was analysed independently as the treatments, time of application, and doses were different in each of the two evaluated cropping seasons. In the first year, the main plot consisted of four rootstocks (G.202, G.213, M.9, and Marubakaido with M.9 interstem). The subplots (within each main plot) were the plant growth regulators (Benzyladenine, $\mathrm{BA}+\mathrm{GA}_{4+7}$, and Thidiazuron). The sub-sub plots were the doses of each growth regulator: (BA: 0, 1250, 2500, and $\left.3750 \mathrm{ml} . \mathrm{L}^{-1}\right),\left(\mathrm{BA}+\mathrm{GA}_{4+7}: 0,1250,2500\right.$, and $\left.3750 \mathrm{ml} \cdot \mathrm{L}^{-1}\right)$, and (Thidiazuron: $0,125,250$, and $375 \mathrm{ml} . \mathrm{L}^{-1}$ ).

In the second year, the main plots consisted of four rootstocks (G. 
Table 4

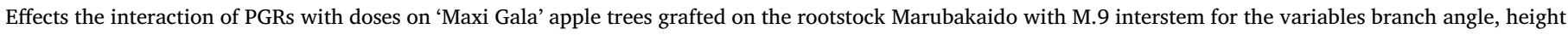
of basal branch, plant height, and spur number.

\begin{tabular}{|c|c|c|c|c|c|c|c|c|c|}
\hline \multicolumn{4}{|c|}{$2015 / 2016$} & \multicolumn{6}{|c|}{$2016 / 2017$} \\
\hline & $\begin{array}{l}\text { Branch } \\
\text { angle }\left({ }^{\circ}\right)\end{array}$ & $\begin{array}{c}\text { Height of } \\
\text { basal } \\
\text { branch } \\
\text { (cm) }\end{array}$ & $\begin{array}{l}\text { Plant } \\
\text { height } \\
(\mathrm{cm})\end{array}$ & $\begin{array}{c}\text { Spur } \\
\text { number }\end{array}$ & & $\begin{array}{l}\text { Branch } \\
\operatorname{angle}\left({ }^{\circ}\right)\end{array}$ & $\begin{array}{c}\text { Height of } \\
\text { basal } \\
\text { branch } \\
\text { (cm) }\end{array}$ & $\begin{array}{l}\text { Plant } \\
\text { height } \\
(\mathrm{cm})\end{array}$ & $\begin{array}{c}\text { Spur } \\
\text { number }\end{array}$ \\
\hline $\begin{array}{l}\text { Dose } \\
\left(\mathrm{ml} \cdot \mathrm{L}^{-1}\right)\end{array}$ & \multicolumn{4}{|c|}{ Benziladenine } & $\begin{array}{c}\text { Dose } \\
\left(\mathrm{ml} \cdot \mathrm{L}^{-1}\right)\end{array}$ & \multicolumn{4}{|c|}{ Benziladenine } \\
\hline$\overline{0}$ & 68 & 34 & 205 & 4 & 0 & 66 & 64 & 199 & 2 \\
\hline 1250 & 60 & 43 & 205 & 5 & 2000 & 63 & 39 & 182 & 9 \\
\hline 2500 & 55 & 33 & 207 & 9 & 3000 & 63 & 34 & 170 & 7 \\
\hline 3750 & 47 & 27 & 161 & 9 & 4000 & 61 & 35 & 177 & 11 \\
\hline Linear & $* * *$ & ns & $*$ & $* * *$ & Linear & ns & $* *$ & $* *$ & $* * *$ \\
\hline Quadratic & ns & ns & ns & ns & Quadratic & ns & ns & ns & ns \\
\hline $\begin{array}{l}\text { Dose } \\
\left(\mathrm{ml} \cdot \mathrm{L}^{-1}\right)\end{array}$ & \multicolumn{4}{|c|}{$\mathrm{BA}+\mathrm{GA}_{4+7}$} & $\begin{array}{c}\text { Dose } \\
\left(\mathrm{ml} \cdot \mathrm{L}^{-1}\right)\end{array}$ & \multicolumn{4}{|c|}{$\mathrm{BA}+\mathrm{GA}_{4+7}$} \\
\hline 0 & 68 & 34 & 205 & 4 & 0 & 70 & 64 & 200 & 3 \\
\hline 1250 & 60 & 46 & 196 & 2 & 2500 & 62 & 48 & 188 & 6 \\
\hline 2500 & 55 & 39 & 205 & 4 & 5000 & 57 & 48 & 188 & 7 \\
\hline 3750 & 49 & 42 & 197 & 6 & 7500 & 57 & 35 & 187 & 10 \\
\hline Linear & $* * *$ & ns & ns & ns & Linear & $* *$ & $*$ & ns & $* * *$ \\
\hline Quadratic & ns & ns & ns & ns & Quadratic & ns & ns & ns & ns \\
\hline $\begin{array}{l}\text { Dose } \\
\left(\mathrm{ml} \cdot \mathrm{L}^{-1}\right)\end{array}$ & \multicolumn{4}{|c|}{ Thidiazuron } & $\begin{array}{c}\text { Dose } \\
\left(\mathrm{ml} \cdot \mathrm{L}^{-1}\right)\end{array}$ & \multicolumn{4}{|c|}{ Cyclanilide+ethephon } \\
\hline 0 & 68 & 34 & 205 & 4 & 0 & 68 & 65 & 192 & 3 \\
\hline 125 & 44 & 34 & 194 & 10 & 25 & 77 & 36 & 192 & 7 \\
\hline 250 & 39 & 33 & 197 & 10 & 50 & 80 & 38 & 205 & 7 \\
\hline 375 & 38 & 30 & 164 & 10 & 75 & 79 & 35 & 176 & 9 \\
\hline Linear & $* * *$ & ns & $*$ & ns & Linear & $*$ & $* *$ & ns & $* *$ \\
\hline Quadratic & ns & ns & ns & ns & Quadratic & ns & $* *$ & ns & ns \\
\hline
\end{tabular}

${ }^{n s}$ Non-significant according to the polynomial orthogonal contrasts. $*$, $* *$, and $* * *$ Significant for $5 \%, 1 \%$ and $0.1 \%$ of probability, respectively.

202, G.213, M.9, and Marubakaido with M.9 interstem). The subplots were the plant growth regulators (Benzyladenine, $\mathrm{BA}+\mathrm{GA}_{4+7}$, and Cyclanilide + ethefon). The sub-sub plots were the doses of each growth regulator: (BA: 0, 2000, 3000, and $4000 \mathrm{ml} \cdot \mathrm{L}^{-1}$ ), (BA $+\mathrm{GA}_{4+7}$ : 0, 2500, 5000, and $7500 \mathrm{ml} . \mathrm{L}^{-1}$ ), and (Cyclanilide + Ethephon: 0, 25, 50 , and $75 \mathrm{ml} . \mathrm{L}^{-1}$ ).

\subsection{Statistical analysis}

The results of the variables branch angle, height of first basal branch, plant height and spur number were subjected to analysis of variance through the $\mathrm{F}$ test $(\mathrm{p} \leq 0.05)$ and in case of significance the treatments means were analyzed by orthogonal polinomial contrasts ( $\mathrm{p} \leq 0.05$ ). For the variables branch number and branch length the data were averaged and calculated the standart deviation to plot graphs, independently for each year. All statistical analysis were performed using SAS (SAS Institute, 2002).

\section{RESULTS}

There was a high significance of the interaction of PGRs with doses, in the first season, in the variable branch crotch angle ( $p \leq 0.001)$. The scions grafted on the rootstock G.202 was significantly affected by BA, as with the increase of the doses, more upright branches were produced (increasing doses made the branches more vertical), while the PGR TDZ did not change the lateral branches crotch angle (Table 1). For the scions grafted on the rootstock G.213 (Table 2) and Marubakaido/M.9 interstem (Table 4), all PGRs significantly affected branch angle following the same pattern of the scions grafted on G.202 (with the increment of the PGR dose, the crotch angle got more upright). Surprisingly, the scions grafted on M.9 had wider angles with all PGRs, proportionally to the increase of the doses (Table 3).

In the second season, for the same variable, a significant interaction of PGRs with doses was found ( $\mathrm{p} \leq 0.001$ ) with a variable response of the scions for each rootstock. For scions grafted on G.202, there was a linear angle decrease accordingly to dose of $\mathrm{BA}$ and $\mathrm{BA}+\mathrm{GA}_{4+7}$, whereas, cyclanilide + ethephon did not affect crotch angle (Table 1). For the scions grafted on G.213 a linear angle decrease was found for $\mathrm{BA}+\mathrm{GA}_{4+7}$, while cyclanilide + ethephon did not affect branch angle in all doses (Table 2). For the scions grafted on M.9, a linear angle decrease was induced by $\mathrm{BA}+\mathrm{GA}_{4+7}$ and a quadratic response was induced by cyclanilide + ethephon with wider angles with the intermediate doses and narrower angles at $375 \mathrm{ml} . \mathrm{L}^{-1}$, which was the maximum dose (Table 3). For the scions grafted on Marubakaido/M.9, a 


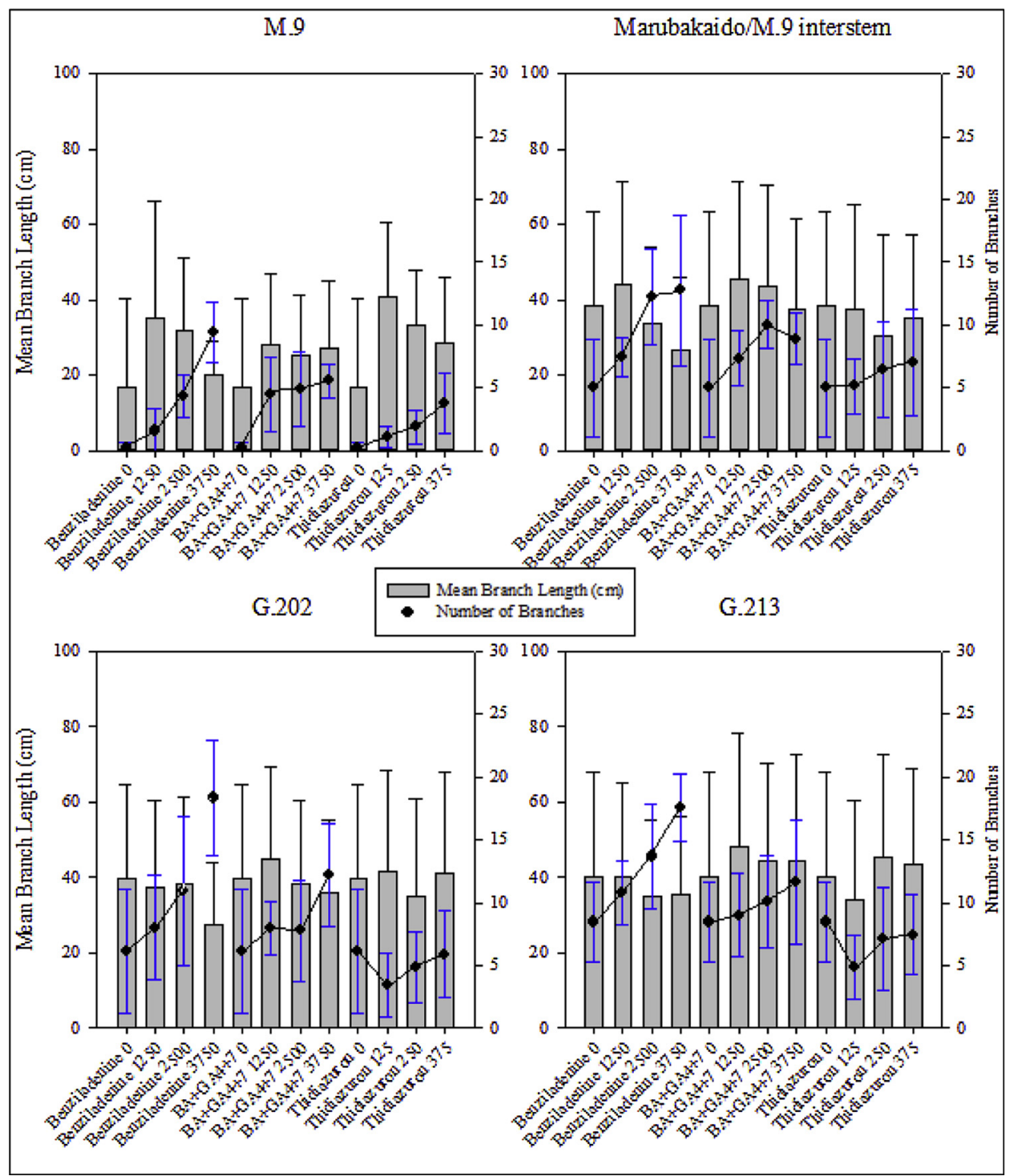

Fig. 1. Effect of plant growth regulators and rates on branch number and mean branch length in the cropping season of 2015/2016. Bars $=$ Mean's standard deviation. "Note: the rates presented at the $\mathrm{x}$ axis are the sum of each rate that was sprayed throughout the season. For BA: $250 \mathrm{ml} . \mathrm{L}^{-1}$ (five times), $500 \mathrm{ml} . \mathrm{L}^{-1}$ (five times), and $750 \mathrm{ml} . \mathrm{L}^{-1}$ (five times); for BA $+\mathrm{GA}_{4+7}: 250 \mathrm{ml} . \mathrm{L}^{-1}$ (five times), $500 \mathrm{ml} . \mathrm{L}^{-1}$ (five times), and $750 \mathrm{ml} . \mathrm{L}^{-1}$ (five times); and for TDZ: $25 \mathrm{ml} . \mathrm{L}^{-1}$ (five times), $50 \mathrm{ml} . \mathrm{L}^{-1}$ (five times), and $75 \mathrm{ml} . \mathrm{L}^{-1}$ (five times).

linear angle decrease of the lateral branches was found with the higher rate of $\mathrm{BA}+\mathrm{GA}_{4+7}$ and a linear angle increase with cyclanilide + ethephon (Table 4). TDZ decreased the crotch angle of the scions grafted on the rootstock G.213 and Mar/M.9, while increased the branch angle of the scions grafted on M.9.

On the variable height of the basal branch on the trunk, in the first season, no effect of dose was found for the PGRs ( $\mathrm{p} \leq 0.94$ ), although proceeding to the orthogonal polynomials it was found for the scions grafted on G.202 and G.213 a linear behaviour only on BA, in which the height of insertion was inversely proportional to the increment of doses (Tables 1 and 2). For the scions grafted on M.9 and Marubakaido/M.9 interstem the doses did not differ from the untreated control (Tables 3 and 4).

In the second season a significant effect of the interaction of PGRs with doses was found ( $\mathrm{p} \leq 0.002)$ for the scions grafted on G.202 and Marubakaido/M.9 interstem, in which all the growth regulators significantly decreased the height of insertion of the basal branch with the increment of the doses (Tables 1 and 4). The scions grafted on the rootstock G.213 presented lower insertion with BA and cyclanilide + ethephon (Table 2), and the scions grafted on the rootstock M.9 emitted lower branches in the trunk with $\mathrm{BA}+\mathrm{GA}_{4+7}$ and cyclanilide + ethephon (Table 3).

As evidenced in Fig. 1, in the first season, for the scions grafted in all rootstocks, the PGRs BA and $\mathrm{BA}+\mathrm{GA}_{4+7}$ indeed increased the number of branches proportionally to the doses. An inconstant response was observed in the second year in the scions for each rootstock (Fig. 2). The better results found for each scion versus rootstocks were: for M.9, $\mathrm{BA}+\mathrm{GA}_{4+7}$ at $5000 \mathrm{ml} . \mathrm{L}^{-1}$, for Marubakaido/M.9 BA at $4000 \mathrm{ml} . \mathrm{L}^{-1}$, for G.202 and G.213 BA + GA $4+7$ at $5000 \mathrm{ml}^{-\mathrm{L}^{-1}}$ and BA at $4000 \mathrm{ml} . \mathrm{L}^{-1}$.

On both years, all PGRs indeed reduced branch length compared to the untreated control even though with little visual difference. Although, for commercial standards, which require the highest number of branches with length around $20 \mathrm{~cm}$, the only treatment that reached the goal was BA at the highest dose on the scions grafted on the rootstock M.9.

There was high significance on the interaction of PGRs with doses ( $\mathrm{p} \leq 0.0001$ ) in the variable spur number (thorns) in both seasons. In the scions grafted on the rootstocks G.202 and M.9 all PGRs significantly enhanced the number of spurs in the nursery trees proportionally to the increment of the doses (Tables 1 and 3). For the 


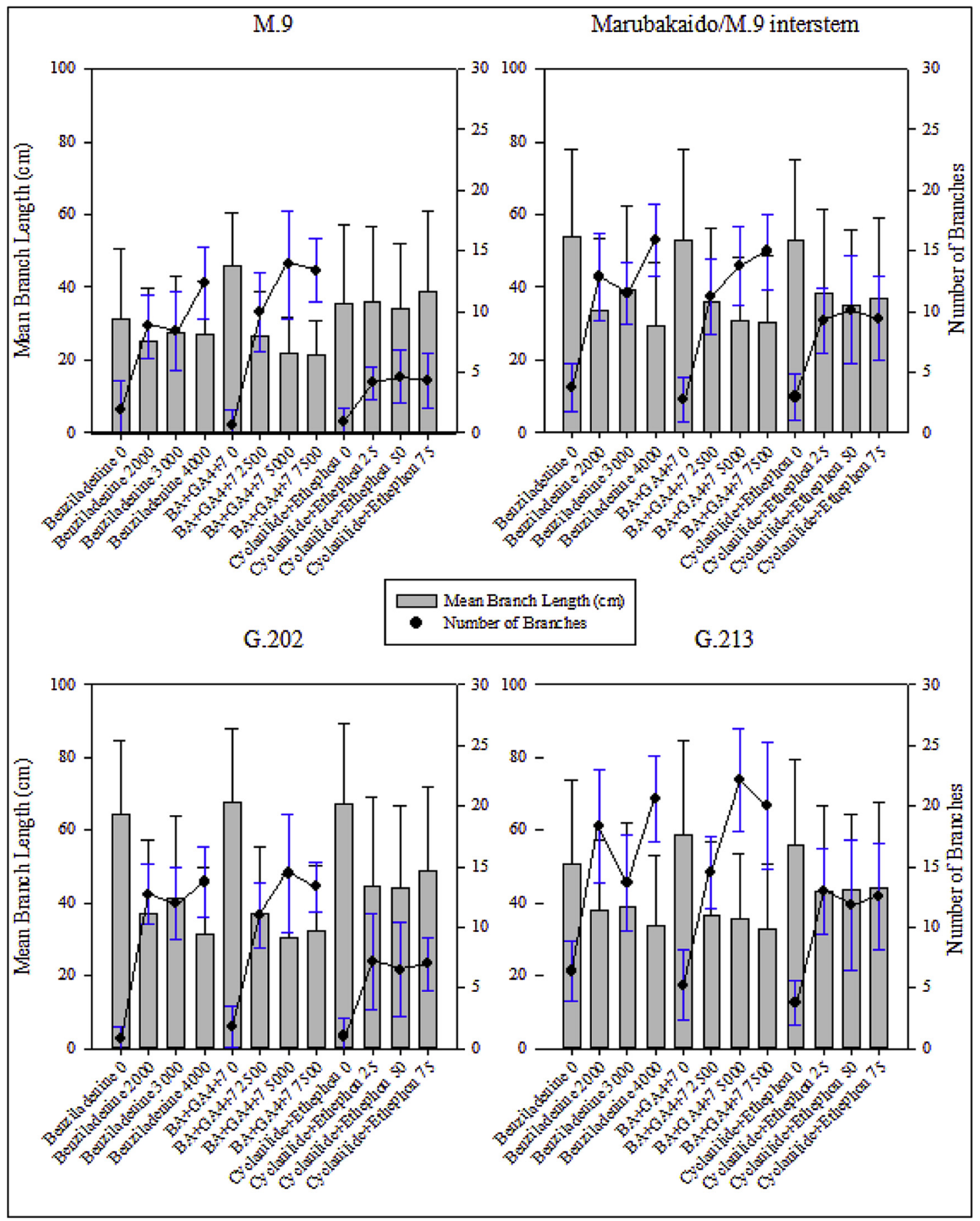

Fig. 2. Effect of plant growth regulators and rates on branch number and mean branch length in the cropping season of 2016/2017. Bars $=$ Mean's standard deviation. *Note: the rates presented at the $\mathrm{x}$ axis are the sum of each rate that was sprayed throughout the season. For BA: $500 \mathrm{ml} . \mathrm{L}^{-1}$ (four times), $1000 \mathrm{ml} . \mathrm{L}^{-1}$ (four times) and $1500 \mathrm{ml} . \mathrm{L}^{-1}$ (two times); for BA $+\mathrm{GA}_{4+7}: 500 \mathrm{ml} \cdot \mathrm{L}^{-1}$ (five times), $1000 \mathrm{ml} \cdot \mathrm{L}^{-1}$ (five times) and $1500 \mathrm{ml} . \mathrm{L}^{-1}$ (five times); for cyclanilide + ethephon: $12.5 \mathrm{ml} . \mathrm{L}^{-1}$ (twice), $25 \mathrm{ml} . \mathrm{L}^{-1}$ (twice) and $37.5 \mathrm{ml} . \mathrm{L}^{-1}$ (twice).

scions grafted on G.213, only TDZ increased spur number (Table 2). And the scions grafted on the rootstock Marubakaido/M.9 interstem only BA enhanced the number of spurs accordingly to the dose (Table 4).

In the second season for the scions of all rootstocks, the increment of the spur number was dependent on the dose; for scions grafted on G.202, BA and cyclanilide + ethephon boosted linearly the number of spurs, while for $\mathrm{BA}+\mathrm{GA}_{4+7}$ the response was quadratic (Table 1). For the scions grafted on G.213 and Marubakaido/M.9 interstem, all the PGRs linearly incremented the number of spurs (Tables 2 and 4). For the scions grafted on M.9, BA and $\mathrm{BA}+\mathrm{GA}_{4+7}$ increased linearly the number of spurs, while cyclanilide + ethephon induced a quadratic response with a decrease at the highest dose (Table 3 ).

In both seasons no significant interaction was found for PGRs with doses ( $\mathrm{p} \leq 0.14$ and $\mathrm{p} \leq 0.35$, respectively) for the variable plant height, although proceeding to the orthogonal polynomials, in the first season, the scions grafted on the rootstocks G.213 and M.9 were significantly reduced by BA accordingly to the enhancement of the doses (Tables 2 and 3). For the scions grafted on Marubakaido/M.9, BA and TDZ reduced plant height with the increment of dose (Table 4). 
Table 5

Effects the interaction of rootstocks with PGRs in 'Maxi Gala' apple trees for the variable root volume in the season of 2015/2016.

\begin{tabular}{lcccc}
\hline \multirow{2}{*}{ PGRs } & \multicolumn{4}{c}{ Root volume $\left(\mathrm{cm}^{3}\right)$} \\
\cline { 2 - 5 } & G.202 & G.213 & Mar./M.9 & M.9 \\
\hline BA & $92 \mathrm{a}^{\mathrm{a}}$ & $78 \mathrm{~ns}$ & $97 \mathrm{~b}$ & $50 \mathrm{~ns}$ \\
$\mathrm{BA}+\mathrm{GA}_{4+7}$ & $73 \mathrm{~b}$ & 89 & $115 \mathrm{a}$ & 51 \\
TDZ & $79 \mathrm{ab}$ & 80 & $89 \mathrm{~b}$ & 50 \\
\hline Mean & 81 & 82 & 100 & 50
\end{tabular}

C.V. $(\%)^{\mathrm{b}}$

20.80

a Means followed by the same letter in a column are not different according to the Fischer's Protected LSD test ( $\mathrm{p} \leq 0.05$ ).

b Coefficient of variation.

In the second season, for the variable plant height, no significant effect was found for the scions grafted on the rootstocks G.202, G.213 and M.9 with all growth regulators (Tables 1, 2 and 3). Although for the scions grafted on Marubakaido/M.9 interstem, a significant linear height reduction was induced by BA (Table 4).

There was significant effect of treatment on root volume (evaluated only in the first season) ( $\mathrm{p} \leq \mathrm{0.02}$ ), on the interaction of rootstocks into PGRs (Table 5). In the scions grafted on the rootstock G.202, the higher root volume was achieved with benzyladenine, while for the scions grafted on Marubakaido/M.9 interstem, the PGR BA $+\mathrm{GA}_{4+7}$ induced a greater root volume, indicating that $\mathrm{BA}$ increased root growth at some extent.

\section{DISCUSSION}

In this experiment, it was noticeable a trend of treatments that induced a higher number of branches, also induced these branches to have a narrower crotch angle. This pattern was also observed by Volz et al. (1994), which in the apple cultivar 'Fiesta' grafted on the dwarfing rootstock M.9, the PGR BA $+\mathrm{GA}_{4+7}$ induced the emission of a higher number of branches, but with the greater branch number, the crotch angle got narrower (upright), and the plants grafted on MM106 (semivigorous rootstock), the branches had a little wider crotch angle with the PGRs. The same authors reported that the untreated control emitted less branches, and so, with narrower crotch angle than the treated trees, that had more branches with wider crotch angle. This phenomenon was likely to be attributed to effective apical dominance interruption by the PGRs, and so additional emission of lateral branches. In opposition to this experiment, for 'Scarletspur Delicious' apple and sweet cherry, cyclanilide at doses ranging from 50 to $200 \mathrm{mg}^{-\mathrm{L}^{-1}}$ did not influence the crotch angle, even though with an increment in the branch number (Elfving and Visser, 2005; Elfving and Visser, 2006).

Johann (1983) found similar results, where benzyladenine $+\mathrm{GA}_{4+7}$ induced more branches, but with narrower crotch angles as the dose of the PGR was increased; in addition, the author reported that M\&B 25105 (an auxin inhibitor similar to cyclanilide) increased the crotch angle of apple plants at nursery, proportionally to the dose. Sazo and Robinson (2011) reported that cyclanilide induced wider crotch angles compared to BA, similarly to this experiment.

It can be noticed in this study that usually the PGRs thidiazuron and cyclanilide + ethephon were the ones which induced the least numbers of lateral branches, but with greater length. With the PGRs BA and $\mathrm{BA}+\mathrm{GA}_{4+7}$, the highest doses promoted higher number of branches although with narrower crotch angles. As a strong apical dominance may lead to wider angles of basal branches, and when these dominant acropetal branches are removed, the ones that were "dominated" are switched to a dominant position and get a more vertical conformation (Ferree \& Schupp, 2003).

Cyclanilide + ethephon did not affected scion's branch angle on the rootstocks G.202, G.213, and slightly on M.9, so it might be due to a stronger apical dominance of the scion's leader, which may indicate that the doses were insufficient to last longer and decrease the trunk's apical dominance, and so keeping lateral branches "dominated" and then with wider crotch angles. It is important to point out that it was not observed for the trees grafted on Marubakaido with M.9 interstem. The response of the scion was dependant on the rootstock, for instance, on the rootstock G.202 no effect was found, for G.213 and Marubakaido with M.9 interstem the PGR promoted narrower crotch angles and, in opposition, on the rootstock M.9 the PGR induced wider crotch angles. It can be hypothesized that on M.9 the apical dominance of the scion is stronger than on G.213 and Marubakaido with M.9 interstem.

In this experiment the reduction of branch angle, which is an indicative of branch vigor, was responsive to cytokinin-like PGRs, as the effect was inversely proportional to rate, that is, as the dose was increased the angle had a tendency to be narrower, and it ought to be explained by the findings of Bangerth et al. (2000), whereby the dominance release of lateral branches caused by apical dominance and hence the IAA basipolar flow, reduces the export of auxin from the dominated buds by increasing the proportion of conjugated auxin; although, when in the presence of locally applied exogenous cytokinins there is a synergistic stimulus on the auxin biosynthesis and a dominated bud may become even more dominant than the central leader due to cytokinin stimulus on IAA biosynthesis at the branch's apical meristem, corroborating with our findings.

Dorić et al. (2015) reported that $\mathrm{BA}+\mathrm{GA}_{4+7}$ promotes a longer branching zone along the apple tree's trunk rather than BA alone, and this response is proportional to the rate at lower doses. Cyclanilide is another potent agent is promoting bud break at the lowest buds, as is has a good mobility in the plant inducing bud break at lower heights (Sazo \& Robinson, 2011), although in our experiment the PGR induced similar or higher height of the basal branch in all rootstocks.

Both BA or BA $+\mathrm{GA}_{4+7}$ increased the number of branches in 'Gala' grafted on MM.106 (vigorous) or M.9 (dwarfing), although BA only may produce more numerous lateral branches than associated with GA (Volz et al., 1994). In our experiment even the smallest dose of BA, $\mathrm{BA}+\mathrm{GA}$ and cyclanilide + ethephon were effective to induce lateral branching. A similar pattern was found by Sazo \& Robinson (2011) with BA, and Cyclanilide and Dorić et al. (2014) with BA, and $\mathrm{GA}_{4+7}+\mathrm{BA}$ were effective in inducing more lateral branches, but not reducing the length as the dose was increased.

These results agree with Volz et al (1994) in which BA and BA + $\mathrm{GA}_{4+7}$ at $1 \mathrm{~g}$ of active ingredient was effective to induce lateral branching and reduce the length in 'Gala' grafted in both vigorous and dwarfing rootstocks; in addition, GA sprays enhance the ability of individual branches to compete and stablish a stronger sink leading to longer branches. Apical dominance is related with a strong auxin production in the apex and downward transportation, inducing permanent dormancy of lateral buds. Cyclanilide shrinks auxin production and transport throughout the plant, favouring the emissions of lateral branching at the dose of $25 \mathrm{ml} . \mathrm{L}^{-1}$ of nursery apple trees, although the authors reported length reduction as the dose was enhanced (Elfving \& Visser, 2005; Elfving \& Visser, 2006).

The source of cytokinins plays an important role in inducing branches and also the length, as in European pears, $\mathrm{BA}+\mathrm{GA}_{4+7}$ was more effective than $\mathrm{TDZ}+\mathrm{GA}_{4+7}$ in inducing sylleptic shoots, and it was expected that cytokinins alone play more important role in inducing thorns and spines, but both TDZ and BA did no differ from the untreated control, while $\mathrm{GA}_{4+7}$ without the presence of any cytokinin greatly induced the emission of thorns (Palmer et al., 2011).

Sylleptic shoots (shoots sprouted in the current year) is a capability determined by the endogenous auxin:cytokinin ratio. The greater level of auxin inhibits bud-break as it antagonizes the effects of the cytokinins. Apple rootstocks play little role in influencing bud-break, but the scion's growth habit (more or less upright growth), as there are multiple factors acting on size controlling capability and more importantly, on 
the endogenous hormone levels. In general, a self-rooted stool rootstock is more invigorating than commercially available rootstocks, and it is expected that those induce a greater apical dominance and few axillary branches as it has higher AXN:CK ratio. The apical dominance can be overcome by any agent capable of diminishing the AXN:CK ratio (Tworkoski and Miller, 2007; Hooijdonk et al., 2011).

As the cytokinins were sprayed on the apical meristem and it antagonizes endogenous auxin down flown to the root system, is tends to increase the ratio of root produced cytokinins to the scion. At early summer, the carbon partitioning of the apple tree priors the allocation to the root growth, as at late summer the response is inverse, that is, the carbon partitioning is mostly allocated to shoot growth. Hence, this response is highly tailed with the endogenous hormone balance, where the levels of cytokinins are higher at early spring as the levels of auxin is low, and at late fall this pattern is switched (Hooijdonk et al., 2011; Bangerth et al., 2000). In addition, the exogenous application of BA in peaches induces root formation and expansion in the soil (Richards and Rowe, 1977).

These results agree with Dorić et al. (2014) in witch both BA and $\mathrm{BA}+\mathrm{GA}_{4+7}$ reduced tree height, specially at the more elevated rates. These PGRs and also cyclanilide promote lateral branching when sprayed multiple times throughout the season, as they promote a shortterm leader growth shortage, thus allowing the lateral buds to break and forming branches; in many reports found on the literature, the use of such PGRs promote a linear tree height decrease inversely proportional to the dose applied, although this response may be different according to the cultivar and weather conditions (Sazo \& Robinson, 2011; Robinson \& Sazo, 2014).

Palmer et al. (2011) reported that cytokinins sprayed alone has a stronger effect on reducing pear tree height, although $\mathrm{GA}_{4+7}$ increases tree height. This could be observed in the current experiment in the rootstocks G.213 and M.9 in the first year and Mar./M.9 in both years, where there was a linear tree height reduction promoted by BA alone proportionally to the rate.

\section{CONCLUSION}

Scions grafted on different rootstocks behave differently to plant growth regulators. 'Maxi Gala' grafted on the rootstocks G.202, M.9, and Marubakaido with M.9 interstem develop more lateral branching, and more spurs with sprays of benziladenine at the highest doses.

Scions grafted on the rootstock G.213 develop longer lateral branching, and higher number of spurs without negatively affecting tree height with the plant growth regulator benzyladenine + gibberellic acid $4+7$ at the highest doses.

Both benzyladenine and $\mathrm{BA}+\mathrm{GA}_{4+7}$ are effective and more reliable in temporarily interrupting apical dominance and inducing more lateral branches. The higher the rate, the greater is the effect of interrupting the trunk's apical dominance and stimulating narrower crotch angles of lateral branches. In contrast, thidiazuron and cyclanilide + ethephon tend to induce less lateral branching, at the tested doses, when compared to both benzyladenine or $\mathrm{BA}+\mathrm{GA}_{4+7}$. Cyclanilide + ethephon at the tested doses is not effective in interrupting the scion's apical dominance on the rootstocks G.202 and G.213, and in improving lateral branching. Whereas, thidiazuron promotes mild apical dominance interruption on the scion grafted on G.213 and Marubakaido with M.9 interstem and M.9.

\section{ACKNOWLEDGEMENTS}

The authors acknowledge: Coordenação de Aperfeiçoamento de Pessoal de Nível Superior (CAPES) for scholarship grant. CNPq and FAPESC for funding. RASIP nurseries for the plant material and space to make the study. EMBRAPA Uva e Vinho for the logistic support and infrastructure.

\section{References}

da Maçã, Anuário Brasileiro, 2017. Santa Cruz do Sul: Editora Gazeta Santa Cruz. pp. $6-52$.

Bangerth, F., Li, C.J., Gruber, J., 2000. Mutual interaction of auxin and cytokinins in regulating correlative dominance. Plant Growth Regulation. 32, 205-217. https:// doi.org/10.1023/A:1010742721004

De Martin, M.C., Petri, J.L., Fenili, C.L., Gabardo, G.C., 2017. Breaking the of dormancy of 'Daiane' apples by using thidiazuron. Revista de Ciências Agroveterinárias. 16 (2), 81-87. https://doi.org/10.5965/223811711622017081.

Denardi, Porta-enxertos, F., 2002. In: Epagri. A cultura da macieira. Florianopolis. Epagri. pp. $169-226$.

Dorić, M., Keserovic, Z., Magazin, N., Milic, B., Miodragovic, M., 2014. Induction of feathers on one-year-old apple trees cultivar golden delicious using benzyladenine and gibberellins 4+7. Contemporary Agriculture. 63 (1-2), 13-21.

Dorić, M., Magazin, B., Milic, B., Keserovic, Z., 2015. Enhancing feathering of one-yearold gala and jonagold apple trees through application of 6-benzylaminopurine and gibberellins. Bulgarian Journal of Agricultural Science. 21 (3), 631-637.

Elfving, D.C., Visser, D.B., 2005. Cyclanilide induces lateral branching in apple trees. HortScience. 40 (1), 119-122.

Elfving, D.C., Visser, D.B., 2006. Cyclanilide induces lateral branching in sweet cherry trees. HortScience. 41 (1), 149-153.

Erez, A., Yablowitz, Z., Aronovitz, A., Hadar, A., 2008. Dormancy breaking chemicals; efficiency with reduced phytotoxicity. Acta Hort. 772, 105-112. https://doi.org/10. 17660/ActaHortic.2008.772.12.

Ferree, D.C., Schupp, J.R., 2003. Pruning and training physiology. In: Ferree, D.C., Warrington, I.J. (Eds.), Apples: botany, production and uses. Cabi Publishing, pp. 319-341.

Hooijdonk, B.V., Woolley, D., Warrington, I., 2011. Rootstocks modify scion architecture, endogenous hormones, and root growth of newly grafted 'Royal Gala' apple trees. J. Amer. Soc. Hort. Sci. 136 (2), 93-102.

Instituto de Pesquisas Agronômicas, 1989. Seção de ecologia agrícola. Porto Alegre: Atlas Agroclimático do Estado do Rio Grande do Sul 1. pp. 102.

Johann, G., 1983. Effect of growth regulators on branching habit of some apple cultivars in the nursery. Acta Hort. 137, 87-93. https://doi.org/10.17660/ActaHortic.1983. 137.8 .

MAPA - Ministério da Agricultura, 2013. Pecuária e Abastecimento. Instrução normativa n²0/2013. Brasília. Available at:. http://www.agricultura.gov.br/assuntos/ sanidade-animal-e-vegetal/sanidade-vegetal/arquivos-prevencao/IN20 2013NeonectriaCancroEuropeu.pdf.

Palmer, J.W., Seymour, S.M., Diack, R., 2011. Feathering of 'Doyenné du Comice' pear in the nursery using repeat sprays of benzyladenine and gibberellins. Scientia Horticulturae 130, 393-397. https://doi.org/10.1016/j.scienta.2011.06.023.

Petry, J.L., Palladini, L.A., Pola, A.C., 2006. Dormência e indução da macieira. EPAGRI: A cultura da macieira. Florianópolis. pp. 261-298.

Richards, D., Rowe, R.N., 1977. Effects of root restriction, root pruning and 6-benzylaminopurine on the growth of peach seedlings. Ann. Bot. 41, 729-740. https://doi. org/10.1093/oxfordjournals.aob.a085347.

Robinson, T.L., Sazo, M.M., 2014. Effect of promalin, benzyladenine and cyclanilide on lateral branching of apple trees in the nursery. Acta Horti. 1042, 293-302. https:// doi.org/10.17660/ActaHortic.2014.1042.35.

SAS Institute, 2002. SAS User's guide: statistics. Software Version 9.0. Cary. NC, USA. .

Sazo, M.M., Robinson, T.L., 2011. The use of plant growth regulators for branching of nursery trees in NY state. New York Quarterly. 19 (2), 5-9.

Streck, E.V., Kämpf, N., Dalmolin, R.S.D., Klamt, E., Nascimento, P.C., Schineider, P., Giasson, E., Pinto, L.F.S., 2008. Solos do Rio Grande do Sul, 2nd ed. Emater/RSASCAR.222p.

Tworkoski, T., Miller, S., 2007. Endogenous hormone concentrations and bud-break response to exogenous benzyl adenine in shoots of apple trees with two growth habits grown on three rootstocks. The Journal of Horticultural Science and Biotechnology. 82 (6), 960-966. https://doi.org/10.1080/14620316.2007.11512333.

Volz, R.K., Gibbs, H.M., Popenoe, J., 1994. Branch induction on apple nursery trees: Effects of growth regulators and defoliation. New Zealand Journal of Crop and Horticultural Science. 22 (3), 277-283. https://doi.org/10.1080/01140671.1994. 9513836. 